Article

\title{
Preparation and In Vitro Evaluation of RITUXfab-Decorated Lipoplexes to Improve Delivery of siRNA Targeting C1858T PTPN22 Variant in B Lymphocytes
}

\author{
Andrea Arena ${ }^{1,+}$, Eugenia Belcastro ${ }^{1,+}\left(\mathbb{D}\right.$, Antonella Accardo ${ }^{2}$, Annamaria Sandomenico ${ }^{3}$, \\ Olivia Pagliarosi ${ }^{1}$ (D), Elisabetta Rosa ${ }^{2}$, Stefania Petrini ${ }^{4}\left(\mathbb{D}\right.$, Libenzio Adrian Conti ${ }^{4}$ (D) Ezio Giorda ${ }^{5}$, \\ Tiziana Corsetti $^{6}$, Riccardo Schiaffini ${ }^{7}$ (D) , Giancarlo Morelli ${ }^{2}$ and Alessandra Fierabracci ${ }^{1, *}$ (D)
}

Citation: Arena, A.; Belcastro, E.; Accardo, A.; Sandomenico, A.; Pagliarosi, O.; Rosa, E.; Petrini, S.; Conti, L.A.; Giorda, E.; Corsetti, T.; et al. Preparation and In Vitro Evaluation of RITUXfab-Decorated Lipoplexes to Improve Delivery of siRNA Targeting C1858T PTPN22 Variant in B Lymphocytes. Int. J. Mol. Sci. 2022, 23, 408. https://doi.org/ 10.3390/ijms23010408

Academic Editor: Arcangelo Liso

Received: 1 December 2021

Accepted: 27 December 2021

Published: 30 December 2021

Publisher's Note: MDPI stays neutral with regard to jurisdictional claims in published maps and institutional affiliations.

Copyright: (C) 2021 by the authors. Licensee MDPI, Basel, Switzerland. This article is an open access article distributed under the terms and conditions of the Creative Commons Attribution (CC BY) license (https:// creativecommons.org/licenses/by/ $4.0 /)$.
1 Infectivology and Clinical Trials Research Department, Bambino Gesù Children's Hospital, Scientific Institute for Research, Hospitalization and Healthcare (IRCCS), 00146 Rome, Italy; aarena026@gmail.com (A.A.); eugenia.belcastro@opbg.net (E.B.); olivia.pagliarosi@opbg.net (O.P.)

2 Research Centre on Bioactive Peptides (CIRPeB), Department of Pharmacy, University of Naples Federico II, 80134 Naples, Italy; antonella.accardo@unina.it (A.A.); elisabetta.rosa@unina.it (E.R.); gmorelli@unina.it (G.M.)

3 Institute of Biostructures and Bioimaging (IBB), National Research Council (CNR), 80134 Naples, Italy; sandomenico@cnr.it

4 Confocal Microscopy Core Facility, Research Laboratories, Bambino Gesù Children's Hospital, Scientific Institute for Research, Hospitalization and Healthcare (IRCCS), 00146 Rome, Italy; stefania.petrini@opbg.net (S.P.); libenzioadrian.conti@opbg.net (L.A.C.)

5 Research Laboratories, Bambino Gesù Children's Hospital, Scientific Institute for Research, Hospitalization and Healthcare (IRCCS), 00146 Rome, Italy; ezio.giorda@opbg.net

6 Unit of Hospital Pharmacy, Bambino Gesù Children's Hospital, Scientific Institute for Research, Hospitalization and Healthcare (IRCCS), 00165 Rome, Italy; tiziana.corsetti@opbg.net

7 Diabetes and Growth Pathology Unit, Bambino Gesù Children's Hospital, Scientific Institute for Research, Hospitalization and Healthcare (IRCCS), 00165 Rome, Italy; riccardo.schiaffini@opbg.net

* Correspondence: alessandra.fierabracci@opbg.net; Tel.: +39-06-6859-2656

+ These authors contributed equally to this work.

\begin{abstract}
Autoimmune endocrine disorders, such as type 1 diabetes (T1D) and thyroiditis, at present are treated with only hormone replacement therapy. This emphasizes the need to identify personalized effective immunotherapeutic strategies targeting $\mathrm{T}$ and B lymphocytes. Among the genetic variants associated with several autoimmune disorders, the $\mathrm{C} 1858 \mathrm{~T}$ polymorphism of the protein tyrosine phosphatase non-receptor type 22 (PTPN22) gene, encoding for Lyp variant R620W, affects the innate and adaptive immunity. We previously exploited a novel personalized immunotherapeutic approach based on siRNA delivered by liposomes (lipoplexes) that selectively inhibit variant allele expression. In this manuscript, we improved lipoplexes carrying siRNA for variant C1858T by functionalizing them with Fab of Rituximab antibody (Ritux $\mathrm{Fab}$-Lipoplex) to specifically target $\mathrm{B}$ lymphocytes in autoimmune conditions, such as T1D. Ritux $\mathrm{Fab}$-Lipoplexes specifically bind to B lymphocytes of the human Raji cell line and of human PBMC of healthy donors. Ritux Fab-Lipoplexes have impact on the function of B lymphocytes of T1D patients upon CpG stimulation showing a higher inhibitory effect on total cell proliferation and IgM+ plasma cell differentiation than the not functionalized ones. These results might open new pathways of applicability of Ritux ${ }_{\text {Fab }}$-Lipoplexes, such as personalized immunotherapy, to other autoimmune disorders, where B lymphocytes are the prevalent pathogenic immunocytes.
\end{abstract}

Keywords: T1D; autoimmune disease; functionalized lipoplexes; rituximab; immunotherapy; variant PTPN22

\section{Introduction}

Autoimmune diseases encompass a broad category of tissue-targeted conditions including organ-specific ones, often affecting endocrine glands like insulin-dependent 
diabetes mellitus (type 1 diabetes, T1D) and thyroiditis, and non-organ specific ones like systemic lupus erythematosus (SLE), vasculitides, rheumatoid arthritis (RA) and systemic sclerosis (SS) [1]. The incidence of autoimmune diseases is increasing worldwide [2]. With reference to endocrine autoimmunity and T1D, the latter especially occurs in children below the age of five [3]. It is generally recognized that autoimmunity is caused by autoreactive effector cells, that is, autoreactive T lymphocytes for T1D whilst autoreactive B lymphocytes play a major role in SLE. Pathogenic T cell precursors result from the defective process of immunological tolerance that takes place in the thymus in perinatal age under the influence of genetic susceptibility and epigenetic modifications and it is triggered by putative exogenous and endogenous environmental agents (i.e., the microbiome) $[4,5]$. Nevertheless, the onset of clinical disease is caused by still unknown eliciting antigens that may be different from those which generate the tolerance breakdown and act after a long preclinical period.

Complexity and heterogeneity are the hallmarks of this category of disorders; therefore, this emphasizes the need to identify more effective strategies for their personalized prevention and treatment. At present, the only available treatment for endocrine organspecific autoimmune disorders is the substitutive administration of the deficient hormone. Therefore, a theoretical advance is the contribution that an immunotherapeutic strategy, by halting the pathogenetic mechanism of disease, may add to preserve the hormonal cells from the autoimmune attack of autoreactive T cells [6].

Several approaches targeting the immune system have already been experimented with, but without success, especially for the treatment of T1D since insulin-independence was not achieved in diabetic patients [7,8]. Indeed, these approaches in particular explored the possibility to target $\mathrm{T}$ lymphocytes, the main pathogenic effectors.

B lymphocytes are also important targets in autoimmunity because they give rise to autoantibody-producing plasma cells and induce CD4+ T cell differentiation by antigen presentation. Moreover, they regulate the organization of the lymphoid system architecture and play a role in co-stimulation, controlling the function of dendritic cells and the secretion of soluble factors, that is, proinflammatory cytokines tumor necrosis factor alpha (TNF- $\alpha$ ), interleukin (IL)-8 and IL-6 [9]. Therefore, B cell modulating therapies in B cell-mediated autoimmune diseases were attempted in order to maintain immune surveillance, eliminate effector B lymphocytes and stimulate regulatory B cells (B-regs) [10]. These strategies have employed Rituximab [11] and anti-CD20 antibodies of a new generation, that is, anti-CD19, -CD22, chimeric autoantibody receptor T (CAAR-T) cells and inhibitors of B cell receptor activation [9]. With variable applications to specific autoimmune conditions, these treatments had limited efficacy or generated adverse effects since they also affected the B-regs cellular subset or halted the humoral antigen recall response thus enhancing risk [12].

In light of the foregoing, tailored approaches of 'personalized medicine' should be attempted especially on the basis of disease susceptibility under genetic influence. With the advent of genome-wide linkage, candidate gene and genome-wide association studies [13], in addition to human leucocytes antigens, several single nucleotide polymorphisms (SNPs) were discovered to contribute to autoimmunity etiopathogenesis [14,15]. In citing examples of candidate common susceptibility genes involved in immune regulation, cytotoxic T lymphocyte-associated antigen 4 (CTLA4) suppresses T cell activation [16], forkhead box P3 (FOXP3) is involved in the differentiation of T regulatory cells (T-regs), the IL-2 receptor alpha/CD25 gene also affects the development and the function of T-regs, and the TNF- $\alpha$ gene, located on chromosome 6p21.3, is at the basis of the increased risk for the association of T1D and autoimmune thyroid disease (rev. in [15]). Among the others, protein tyrosine phosphatase non-receptor type 22 (PTPN22), encoding for the lymphoid tyrosine phosphatase (Lyp), affects the TCR signaling pathway. The C1858T polymorphism of PTPN22, which replaces the amino acid Arg (R) 620 with Trp (W) (R620W), encodes for a more active phosphatase, namely Lyp variant R620W. This is a potent inhibitor of T cell activation involved in several autoimmune diseases $[17,18]$. The variant is supposed to 
have important effects at the level of thymocyte tolerization [18]. In particular, the C1858T allelic variant represents a genetic risk factor for T1D [17,19-21], Graves' disease [22], the association of T1D and autoimmune thyroid disease known as autoimmune polyglandular syndrome type 3 variant (APS3v) (rev. in [6]) and myasthenia gravis [23]. Even for non-organ specific autoimmune diseases of complex pathogenesis, the association with the PTPN22 polymorphism was observed in Caucasians, that is, SLE (rev. in [20,24]), Wegener's granulomatosis [25] and RA patients [18,26].

We provided evidence that the C1858T PTPN22 gene polymorphism $[6,18]$ could be a relevant target for immunomodulation in the treatment of $\mathrm{C} 1858 \mathrm{~T}$ patients affected by an autoimmune disease, that is, T1D [6,27]. In particular, we demonstrated the possibility of achieving target down-modulation of variant C1858T PTPN22 gene by delivering siRNA molecules with liposomes to peripheral blood mononuclear cells (PBMC) in culture [6]. Strategies can be implemented to improve the targeted delivery of lipoplexes to specific immunotypes playing a major role in the autoimmune disease pathogenesis. On a theoretical basis, this can be unraveled by using monoclonal antibodies that drive nanoparticles to $T$ or B lymphocytes through Food and Drug Administration (FDA) approved humanized monoclonal antibodies (MoAbs) [28-30]. In light of the foregoing, the aim of this manuscript was to evaluate the possibility of generating functionalized lipoplexes with Fab of anti-CD20 (Rituximab) [30] in order to target B lymphocytes in autoimmune diseases.

\section{Results}

\subsection{Preparation of Proteolytic Fab' Fragment}

Fragment antigen binding $(\mathrm{Fab})$ of Rituximab ( Ritux $_{\mathrm{Fab}}$ ) was prepared by reduction of the $\mathrm{F}\left(\mathrm{ab}^{\prime}\right)_{2}$ of Rituximab (Ritux $\mathrm{Fab2}_{2}$ ) obtained by a standard proteolytic cleavage with pepsin. Analytical size exclusion chromatography (SEC)-HPLC showed that both Ritux $\mathrm{Fab2}_{2}$ and Ritux $\mathrm{Fab}_{\mathrm{F}}$ were purified to homogeneity (purity over $95 \%$, Supplementary Figure S1A,B). Sodium dodecyl sulphate-polyacrylamide gel electrophoresis (SDS-PAGE) analysis showed

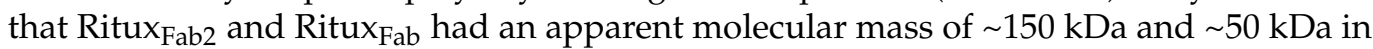
native conditions, respectively (Figure 1 ).

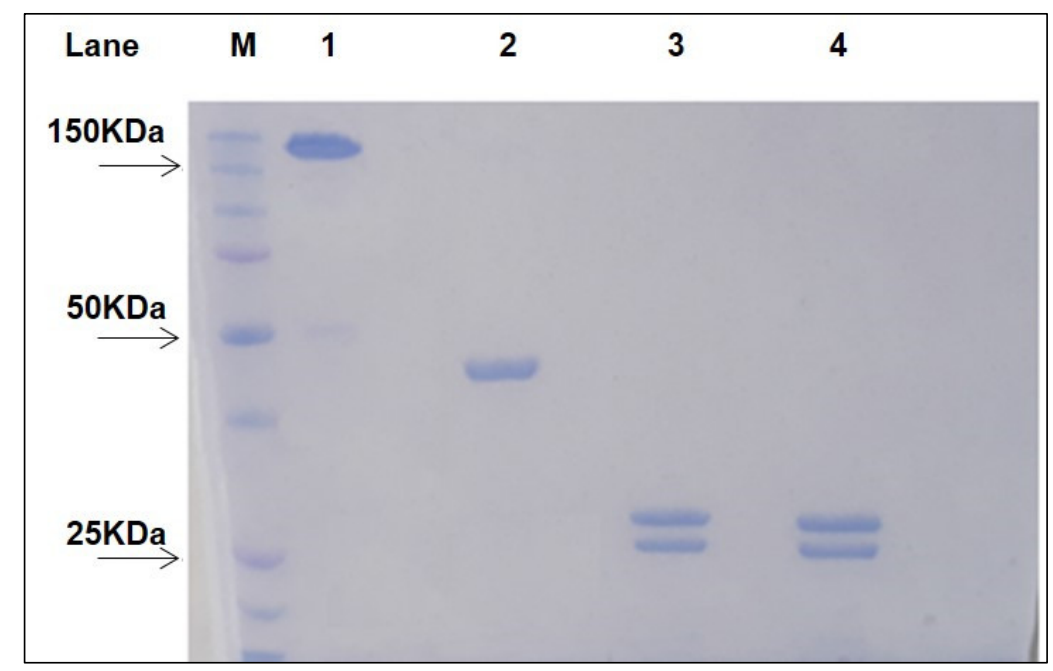

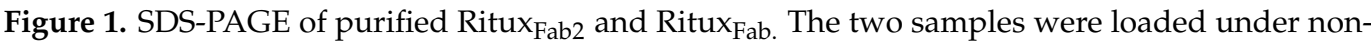
reducing and reducing (lanes 3-4) conditions, respectively. Lane 1: non reduced Ritux $\mathrm{Fab2}_{2}$ Lane 2: non reduced Ritux $\mathrm{Fab}$; Lane 3: reduced Ritux $_{\mathrm{Fab} 2}$; Lane 4: reduced Ritux $\mathrm{Fab}_{3}$; Lane M: Protein Precision Blue MW Marker (Biorad) used as reference.

Upon reduction, the products were stained as two bands at about $25 \mathrm{kDa}$ and $23 \mathrm{kDa}$, corresponding to the heavy (HC) and light chains (LC), respectively. The sequences of the LC and HC (residues 1-238) of Rituximab are reported in Figure 2 (https:/ / go.drugbank. com/drugs/DB00073, accessed on 10 November 2021). The HC was cut by pepsin at the 
C-terminus of L238 leaving, after the reduction of $\mathrm{F}(\mathrm{ab})_{2}$, cysteine 230 and cysteine 233 side chains as free thiols. Ritux $\mathrm{Fab}_{2}$ and Ritux $\mathrm{Fab}_{\mathrm{F}}$ were analyzed by liquid chromatography coupled with electrospray ionization ion-traptime-of-flight mass spectrometry (LC-ESITOF-MS) after extensive reduction. The chromatogram showed the two distinct chains eluted at different retention times according to their hydrophobicity (LC and HC eluted at 13.9 and $14.8 \mathrm{~min}$ (min), respectively) (Supplementary Figure S2A). Deconvolution of mass/charge spectra of the separated chains revealed that both experimental molecular weights (MWs) were in agreement with those calculated (average MW), considering the partial reformation of the intradomain disulphide bridges. For the LC, an experimental MW of 23,035.82 Da (Supplementary Figure S2B), which was comparable to the calculated value of $23,038.33 \mathrm{Da}$, was observed. The $\Delta$ mass of $-2.51 \mathrm{Da}$ suggested that the two intramolecular bridges were partially reformed. For the $\mathrm{HC}$, an experimental MW of 25,154.86 Da (Supplementary Figure S2C), which is comparable to the calculated value of $25,175.53 \mathrm{Da}(\Delta$ mass $=-20.67 \mathrm{Da})$, was observed. In this case, the $\mathrm{N}$-terminal glutamine was fully converted to pyroglutamic acid $(\Delta$ mass $=-17.03 \mathrm{Da})$ and the two intramolecular bridges were almost fully reformed $(\Delta$ mass $=-4.0 \mathrm{Da})$. Considering these modifications, the calculated MW was 25,154.50 Da and the $\Delta$ mass with the experimental value was only $=-0.36 \mathrm{Da}$. In order to confirm the occurrence of free cysteines in the hinge region of the $\mathrm{HC}$ a reaction of alkylation with 4-[(isopropylaminomethyl] phenylamine (IAM) $(\Delta$ mass $=+57.02 \mathrm{Da})$ was also performed on the Ritux $\mathrm{Fab}_{\mathrm{F}}$ in native conditions and the MW was again evaluated by LC-ESI-TOF analysis under reducing conditions. The HC was detected as three main species corresponding to the polypeptide modified with one, two or three IAMs, with the double modified chain being the prevailing species. The MWs of the three species were: HC+1 IAM, experimental MW 25,211.06 Da, calculated MW 25,211.50 Da; HC+2 IAM, experimental MW 25,268.54 Da, calculated MW 25,268.52 Da; HC+3 IAM, experimental MW 25,325.33 Da, calculated MW 25,325.52 Da. The presence of the triple modified HC was likely due to an alkylation occurring after reduction. The fluorescein isothiocyanate (FITC)-labelled Ritux ${ }_{\text {Fab }}$ was also characterized by LC-ESI-TOF analysis under reducing conditions. The MW of the LC was detected as two main species corresponding to the unmodified polypeptide (experimental MW 23,035.75 Da) and to the single modified product (experimental MW 23,425.60 Da, $\Delta$ mass $=+389.38 \mathrm{Da}$ ). The HC was identified as three main species corresponding to the unlabeled HC (experimental MW 25,155.25 Da), and to the single and double FITC-modified HC (experimental MWs: $25,544.42 \mathrm{Da}, \Delta$ mass $=+389.38 \mathrm{Da} ; 25,933.81 \mathrm{Da}, \Delta$ mass $=+778.56 \mathrm{Da})$.

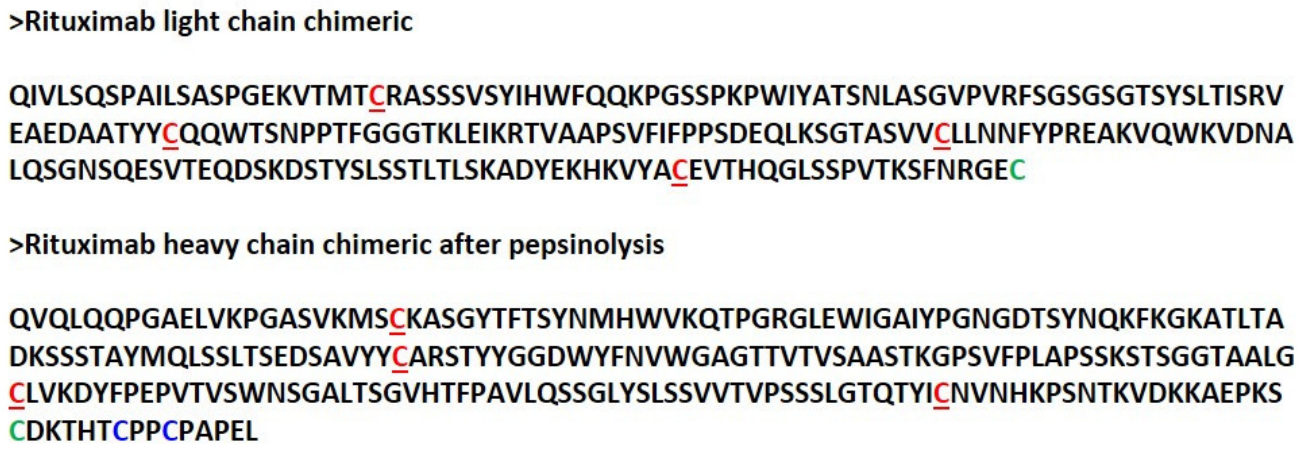

Figure 2. Aminoacidic sequence of intact LC and HC of Rituximab as cut following pepsin hydrolysis. Cysteine involved in intrachain disulfide bridges are underlined and reported in red. C224 of the HC and C213 of the LC that connect the chains are reported in bold green. The free cysteines present in the $\mathrm{Fab}^{\prime}$ hinge region in the $\mathrm{HC}$ are in bold blue.

\subsection{Circular Dichroism (CD) Structural Characterization}

$\mathrm{CD}$ analysis was performed on Ritux $\mathrm{Fab}_{2}$ and Ritux $\mathrm{Fab}_{\mathrm{Fa}}$ fragments to evaluate proper folding in terms of secondary structure and stability. CD spectra recorded in the far- 
UV region (Figure 3A-C) showed that fragments adopted a classical $\beta$-sheet secondary structure according to the Ig-like folding, with a negative band at $219 \mathrm{~nm}$ and a positive one at $205 \mathrm{~nm}$. Thermal denaturation performed by monitoring the CD signal at $218 \mathrm{~nm}$ from $20{ }^{\circ} \mathrm{C}$ to $95^{\circ} \mathrm{C}$ revealed a melting temperature (Tm) of $75^{\circ} \mathrm{C}$ for Ritux $x_{\mathrm{Fab} 2}$ and $74{ }^{\circ} \mathrm{C}$ for Ritux $_{\text {Fab }}$ (Figure 3B-D). The data suggested that the proteolytic fragments retain a correct folding and stability comparable to that of the whole antibody.
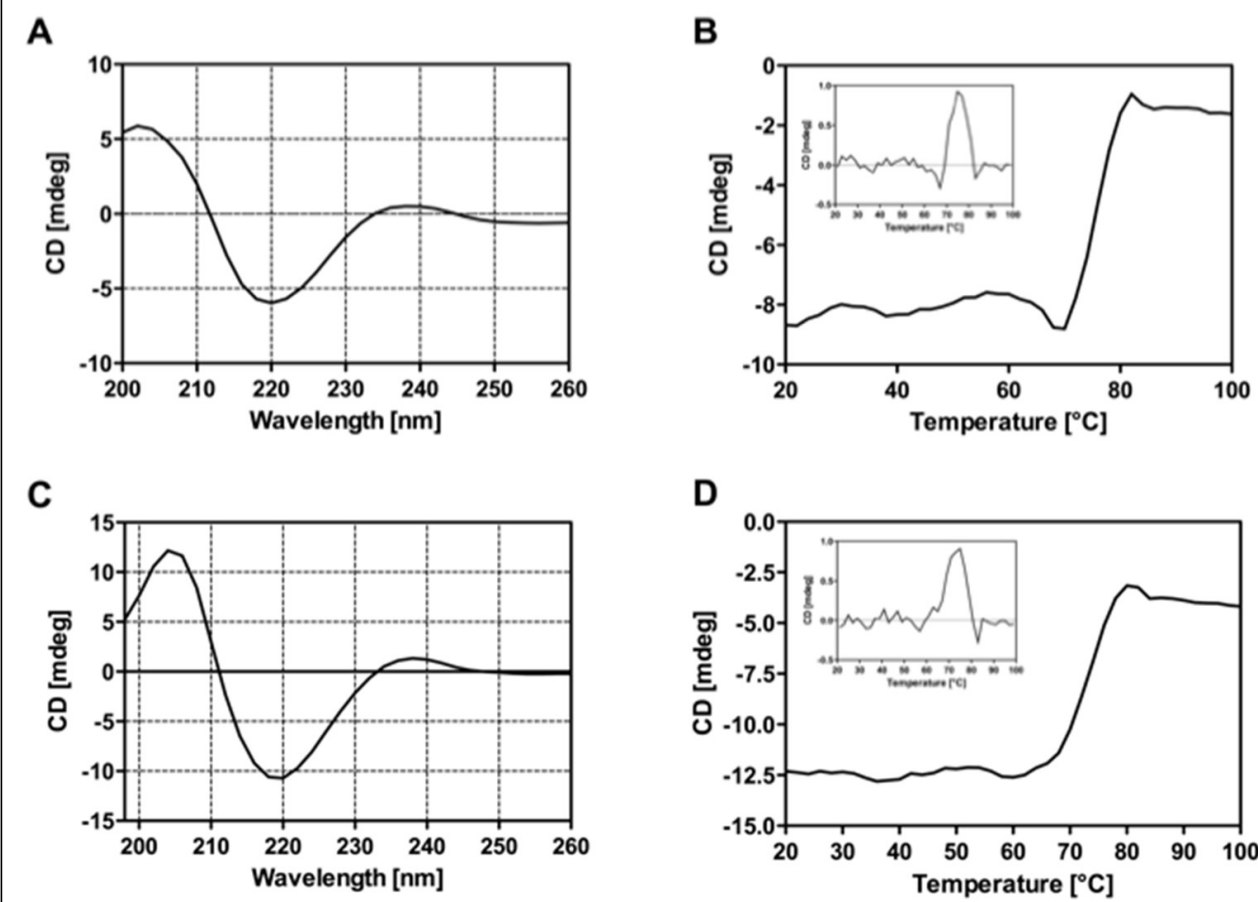

Figure 3. Panel of CD analyses. Far-UV spectra of $\operatorname{Ritux}_{\mathrm{Fab} 2}(\mathrm{~A})$ and Ritux $\mathrm{Fab}(\mathrm{C})$ recorded at the concentration of $4 \mu \mathrm{M}$ at $20^{\circ} \mathrm{C}$. Denaturation curves were collected between $20{ }^{\circ} \mathrm{C}$ and $95{ }^{\circ} \mathrm{C}$ monitoring the CD signal at $218 \mathrm{~nm}$. $\operatorname{Ritux}_{\mathrm{Fab} 2}(\mathbf{B})$ and $\operatorname{Ritux}_{\mathrm{Fab}}(\mathbf{D})$.

\subsection{Lipoplex Formulation and DLS Characterization}

Cationic liposomes were prepared using commercial phospholipid, 1,2-Dioleoyl-snglycero-3-phosphoethanolamine (DOPE), N-[1-(2,3-Dioleoyloxy)propyl]-N,N,Ntrimethylammonium chloride (DOTAP), 1,2-distearoyl-sn-glycero-3-phosphoethanolamine$\mathrm{N}$-[maleimide(polyethylene glycol)-2000] (ammonium salt) (DSPE-PEG2000-Maleimide) (DOPE/DOTAP/DSPE-PEG2000-Maleimide) in 47.5/47.5/5 molar ratio. Briefly, the lipidic film prepared in chloroform was hydrated in phosphate buffer saline (PBS) at $\mathrm{pH}$ 7.4. Then, the suspension was sonicated for $30 \mathrm{~min}$ and extruded 10-times through a $0.1 \mu \mathrm{m}$ polycarbonate membrane. Lipoplexes were prepared incubating the liposomal solution with siRNA at room temperature (RT) for $3 \mathrm{~h}(\mathrm{~h})$. In this preparation, the amount of siRNA was $3.2 \mu \mathrm{M}$. Targeted Ritux $\mathrm{Fab}$-Lipoplexes were obtained by functionalizing the lipoplex with Ritux ${ }_{F a b}$. The coupling reaction was obtained by reacting overnight $(\mathrm{ON})$, under nitrogen, the Fab' thiol function with the maleimide group, according to the Michael addition reaction. Functionalized lipoplex were purified from free Fab' by gel filtration. All the aggregates were structurally characterized by dynamic light scattering (DLS) technique. Intensity profiles of liposomal preparation are reported in Figure 4. From the inspection of the figure, it can be observed that all the distributions are monomodal with one slow diffusion mode around $150 \mathrm{~nm}$. Moreover, no significant changes in the size of aggregates were observed after functionalization of the lipoplex surface with Fab'. Fluorescent lipoplexes were obtained by inserting lipophilic dye (such as Rho-PE) in the liposome formulation and functionalizing the liposomal surface with a small amount of Ritux $\mathrm{Fab}$-FITC. 


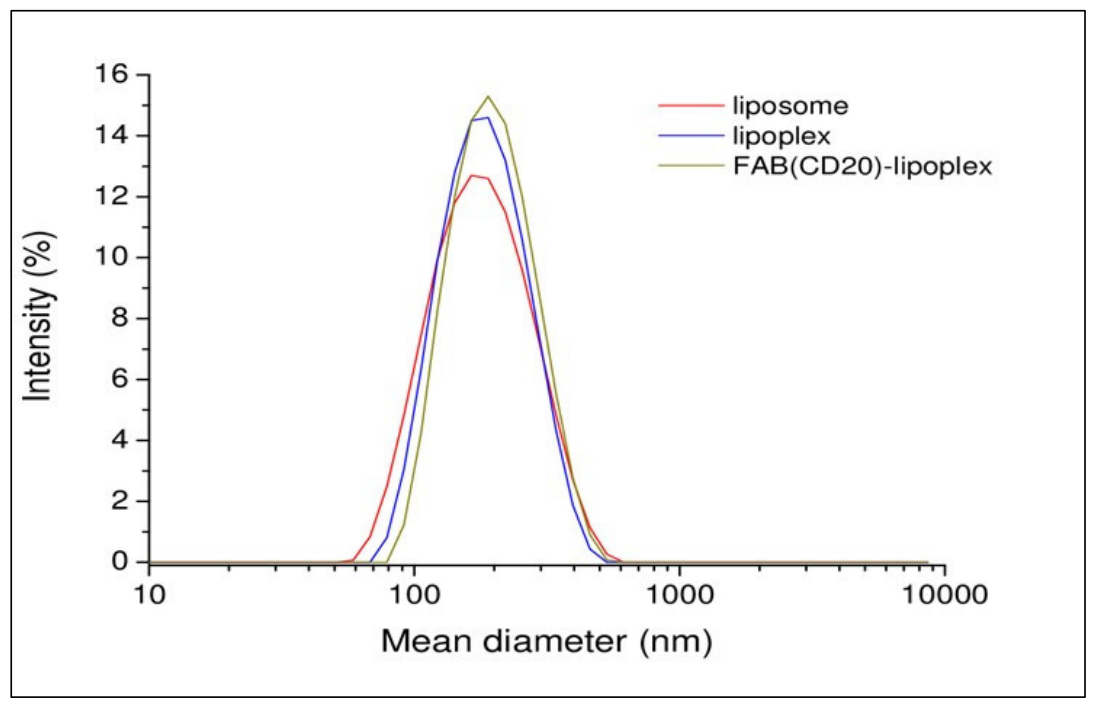

Figure 4. Intensity profiles of liposomal formulations.

\subsection{Ritux $F a b$ and Liposomes Functionalized with Ritux $F a b$ Specifically Bind to Raji Cells}

Flow cytometry analysis (FACS) detected specific reactivity FITC-Ritux $\mathrm{Fab}_{\text {fo }}$ to lymphocytes of the Raji cell line (human B lymphocyte; Burkitt's lymphoma) as revealed by mean fluorescence intensity (MFI) values (Figure 5B). Further, the mixture composed of liposomes functionalized with Ritux $\mathrm{Fab}_{\mathrm{F}} /$ FITC-Ritux $\mathrm{Fab}(90 / 10 \mathrm{~mol} / \mathrm{mol})$ binded efficiently and with high specificity to cells of the B lymphoma Raji cell line (Figure 5C, Supplementary Figure S3).

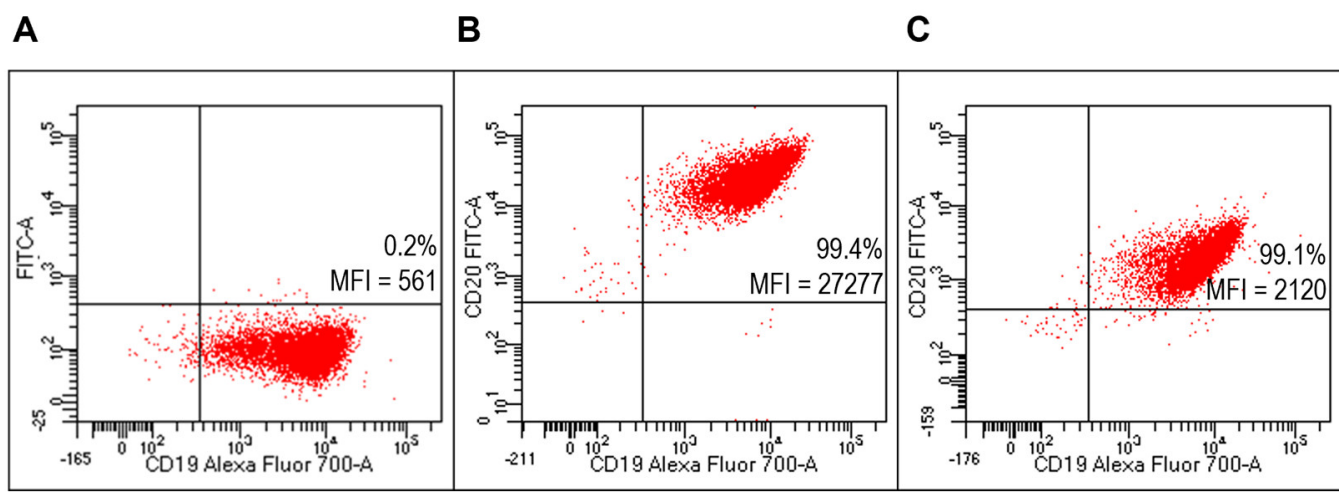

Figure 5. Evaluation of FITC-Ritux ${ }_{\text {Fab }}$ functionalized liposomes on Raji cells (B-cell lymphoma line). Representative FACS profiles indicating the MFI values of FITC-Ritux ${ }_{\text {Fab }}$ among Raji cells. Cells were stained with the anti-CD19-Alexa Fluor 700 (A) and FITC-Ritux ${ }_{F a b}($ B) or liposomes functionalized with Ritux Fab $_{\text {FITC-Ritux }}$ Fab $(90 / 10 \mathrm{~mol} / \mathrm{mol})$ (C).

\subsection{Ritux $F a b$ and Liposomes Functionalized with Ritux $F a b$ Specifically Bind to B Lymphocytes} within Human PBMC

FACS analysis detected specific reactivity of FITC-Ritux $\mathrm{Fab}_{\mathrm{Fa}}$ to $\mathrm{B}$ lymphocytes within the human PBMC pool from healthy donors (HD) (Figure 6B, Supplementary Figure S4). Further, the mixture composed of liposomes functionalized with Ritux $_{\mathrm{Fab}} /$ FITC-Ritux $\mathrm{Fab}$ $(90 / 10 \mathrm{~mol} / \mathrm{mol})$ binded efficiently and with high specificity to B lymphocytes within the

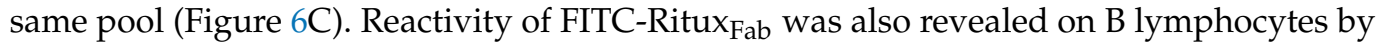
confocal microscopy analysis (Figure 7). 
A

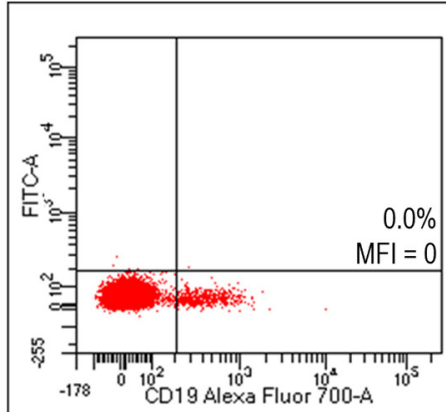

B

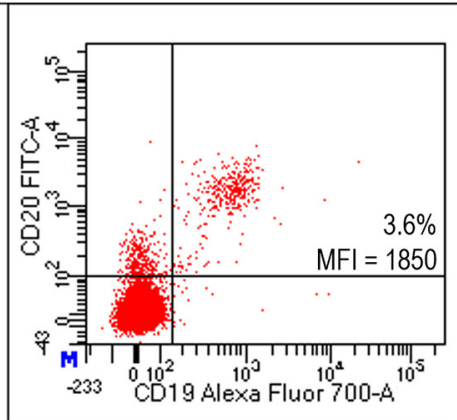

C

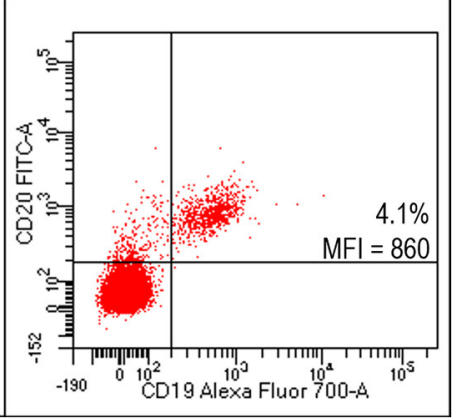

Figure 6. Evaluation of liposomes derivatized with FITC-Ritux $\mathrm{Fab}$ on HD PBMC. Representative FACS profiles indicating the MFI values of FITC-Ritux ${ }_{F a b}$ labelled among HD PBMC. Cells were

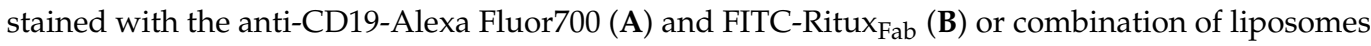
functionalized with Ritux $\mathrm{Fab} /$ FITC-Ritux $\mathrm{Fab}(90 / 10 \mathrm{~mol} / \mathrm{mol})(\mathrm{C})$.

\section{A}
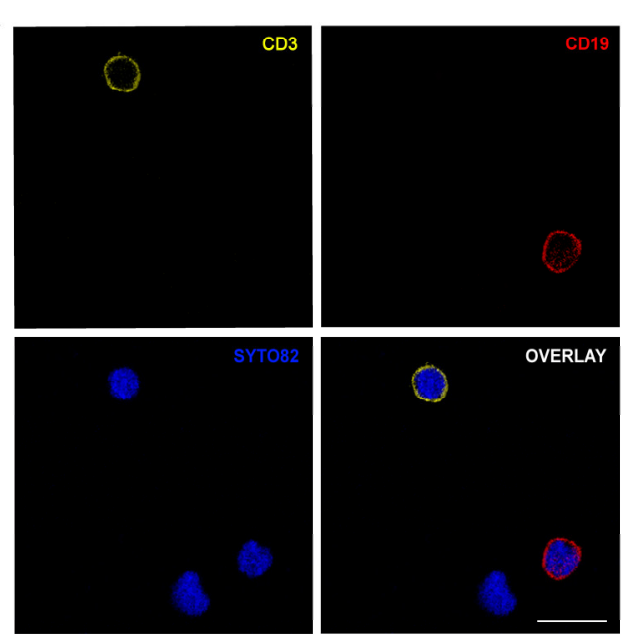

B
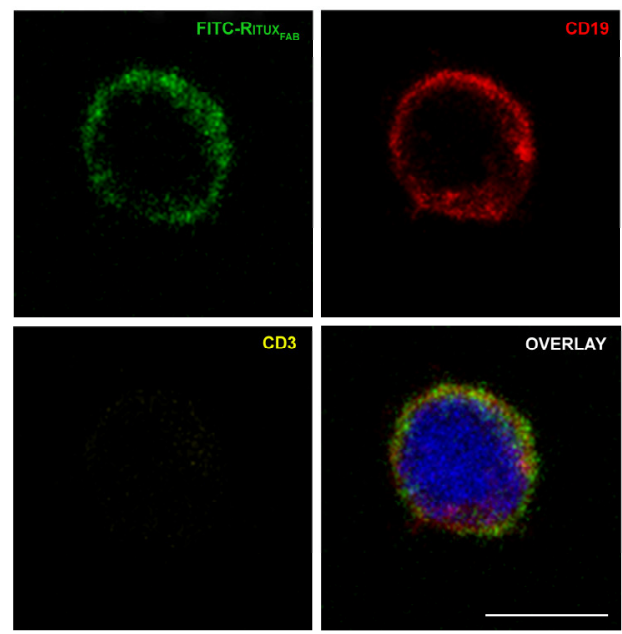

Figure 7. Confocal microscopy analysis of FITC-Ritux $\mathrm{Fab}_{\text {in }}$ HD PBMC. Images show the expression of CD3+ (pseudocolored in orange, upper left panel) and CD19+ (red, upper right panel) cells (A) and the presence of FITC-Ritux $\mathrm{Fab}$ (green, upper left panel) in CD19+ (red, upper right panel) cells and the simultaneous absence in CD3+ (orange, lower left panel) (B) among lymphocytes within the human PBMC pool from HD. Cell nuclei are counterstained with SYTO ${ }^{\mathrm{TM}} 82$ dye (pseudocolored in blue). Scale bars $=10 \mu \mathrm{m}(\mathbf{A})$ and $5 \mu \mathrm{m}(\mathbf{B})$. 


\subsection{Targeted Lipoplexes Specifically Bind to Human B Lymphocytes}

Lipoplexes functionalized with FITC-Ritux ${ }_{F a b}$ specifically binded to Raji cells (Figure 8C) compared to unlabeled lipoplex (Figure 8A). They also specifically binded to $\mathrm{B}$ lymphocytes within the human HD PBMC pool (Figure 9C).

A

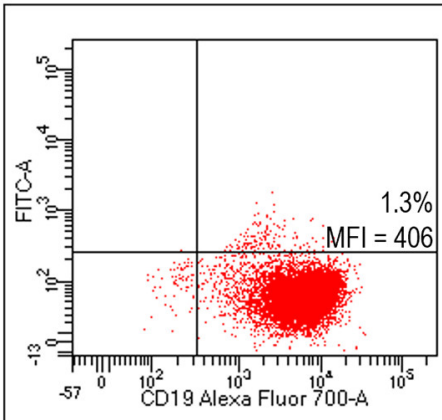

B

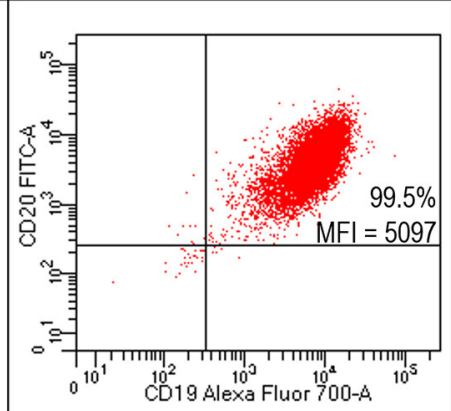

C

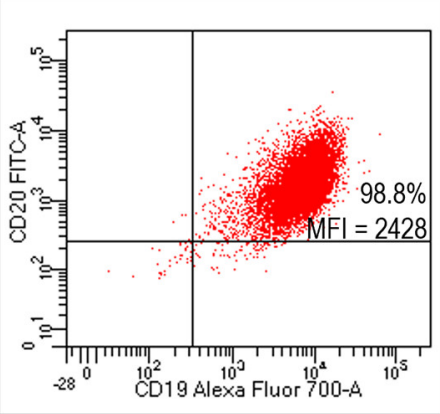

Figure 8. Evaluation of targeted lipoplexes on Raji cell line. Representative FACS profiles indicating the percentages of $\mathrm{Fab}(\mathrm{CD} 20)$-FITC+ among Raji cells after staining with unlabeled and untargeted lipoplex (A), FITC-Ritux $\mathrm{Fab}$ (B) or targeted lipoplex (C).

A

B

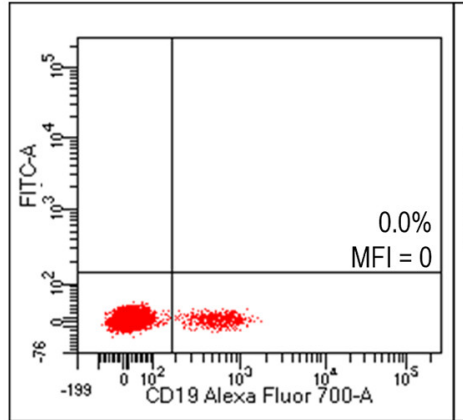

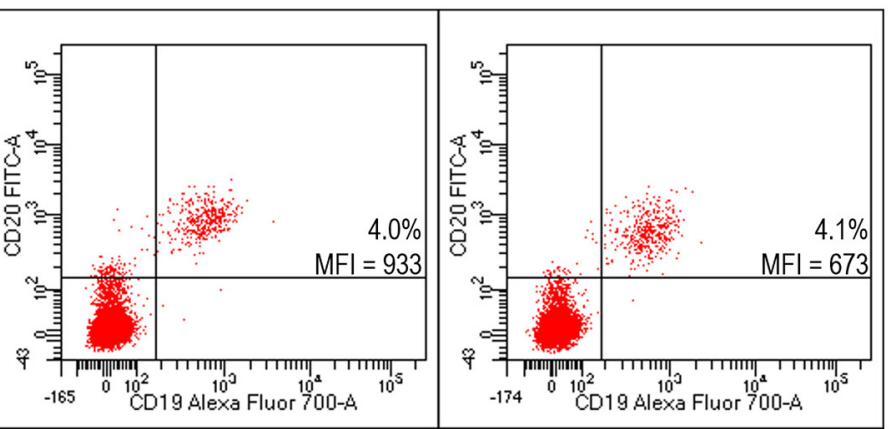

Figure 9. Evaluation of targeted lipoplexes on HD PBMC. Representative FACS profiles indicating the percentages of $\mathrm{Fab}(\mathrm{CD} 20)$-FITC + among lymphocytes after staining with unlabeled and untargeted

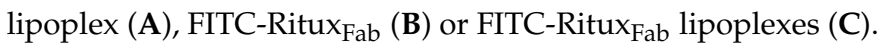

By using targeted lipoplex labeled with 1,2-dioleoyl-sn-glycero-3phosphoethanolamine-N-(7-nitro-2-1,3-benzoxadiazol-4-yl) (ammonium salt) (NBD-PE) fluorophore, we verified their specific MFI fold increase of binding to CD19+ cells on the Raji human cell line (Supplementary Figure S5) and on B lymphocytes within HD PBMC (Supplementary Figure S6) than using the corresponding untargeted lipoplexes.

\subsection{Effect of Functionalized Lipoplexes on $C p G$-Stimulated B Lymphocytes within} Human PBMC

The B cell phenotypes of the PBMC from T1D patients carrying the C1858T PTPN22 variant after treatment of targeted and untargeted lipoplexes at 80 and 100 pmols of siRNA were analyzed after 4 days of $\mathrm{CpG}$ oligodeoxynucleotides stimulus (Figure 10). A significant decrease in the proliferative response (calculated as ratio of proliferation of CD19+ cells over unstimulated cells (RPMI)) was observed with targeted lipoplexes with both doses (Figure 10A). 


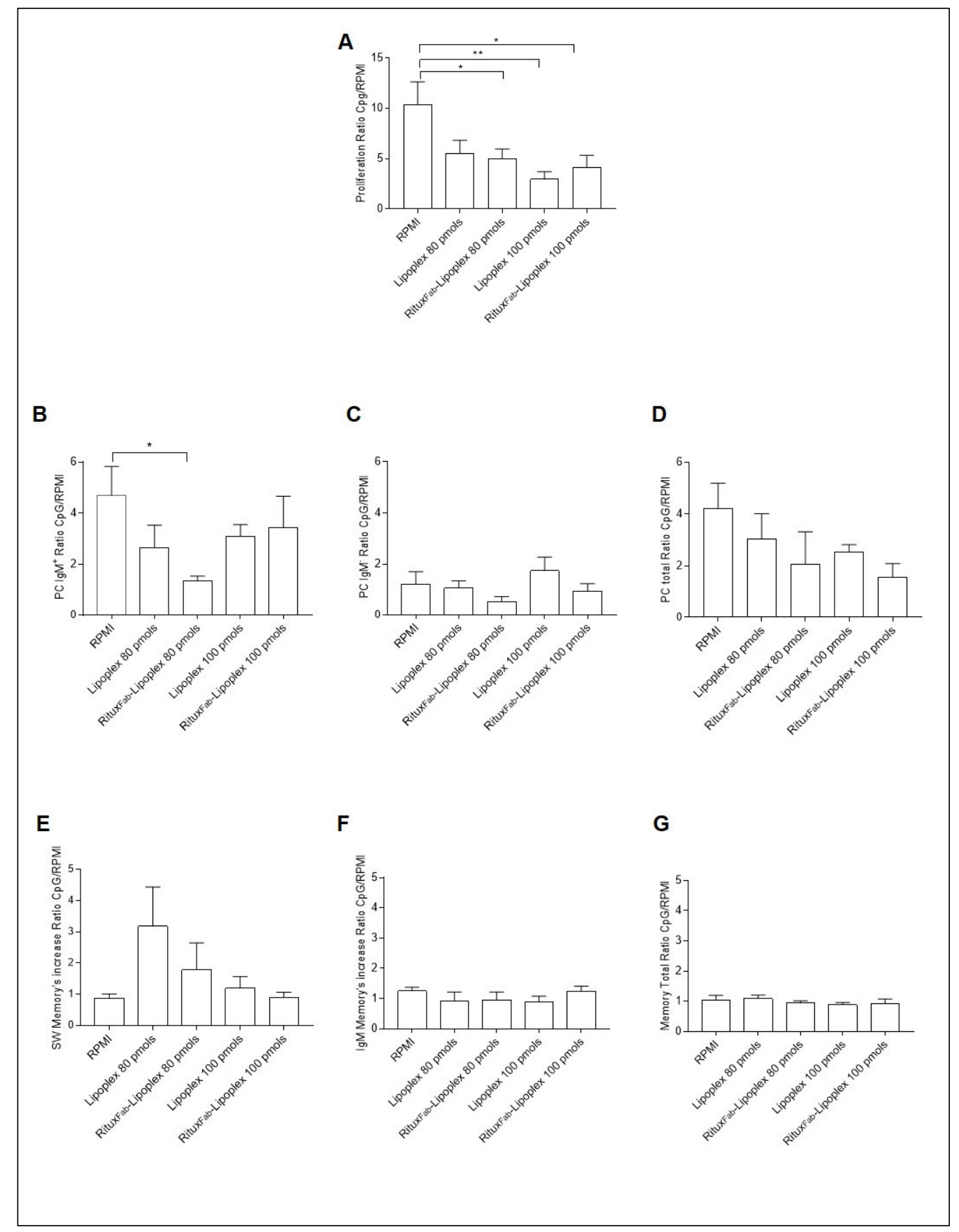

Figure 10. B cell phenotype after 4 days of CpG stimulation in T1D patients carrying the C1858T PTPN22 variant after treatment with lipoplex and Ritux ${ }_{F a b}$-Lipoplex at different doses. Ratio of proliferation of CpG stimulated over unstimulated CMFDA-labelled CD19+ cells (A), ratio of plasma cells from IgM+ (B), IgM- (C) and total (D) memory B cells. Ratio of switched memory (SW) B cell (E), IgM+ memory B cells (F) and total memory B cells (G). Data are expressed as mean \pm SEM of $n=5{ }^{*} p<0.05,{ }^{* *} p<0.01$.

Regarding the specific immunophenotype, the ratio of plasma cells from $\operatorname{IgM}+$ memory $B$ cells showed a higher inhibitory effect with lipoplex at the respective concentration (Figure 10B).

\section{Discussion}

In this manuscript, we provided evidence of the feasibility of exposing Fab of a MoAb, that is, Rituximab on lipoplexes delivering siRNA against the C1858T PTPN22 variant. 
Indeed, functionalized lipoplexes bound themselves with high specificity to B lymphocytes of the human Raji cell line and within the PBMC pool. Remarkably, as revealed by FACS

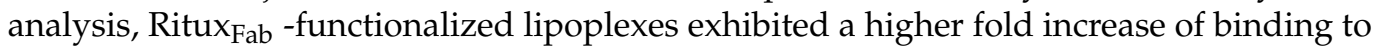
B lymphocytes of the human Raji cell line and of PBMC than not functionalized lipoplexes. This evidence suggests that functionalization does not affect the biofunctionality of Ritux $\mathrm{Fab}_{\text {. }}$

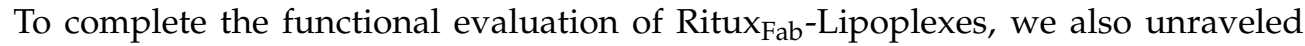
whether they could have a significant effect on the function of B lymphocytes with respect to unfunctionalized lipoplex in comparison to lipoplex following CpG stimulation in PBMC of an exemplary autoimmune disease, that is, T1D. Indeed, we previously observed altered B cell homeostasis and Toll-Like receptor 9-driven response in T1D carriers of the PTPN22 C1858T allelic variant [31,32]. Data demonstrated that the IgM+ memory B cells were significantly increased in heterozygous (1858C/1858T) T1D patients compared to $\mathrm{C} / \mathrm{C}$ individuals and in the groups of individuals who were heterozygous for the variant compared to $\mathrm{C} / \mathrm{C}$ individuals [31]. As regards the functionalization of nanosystems like polymeric micelles and liposomes with antibodies [33] or other homing entities [34] has been widely described as a suitable strategy to achieve an "active targeting" towards specific tissues/cells overexpressing receptors, thus avoiding side effects on healthy tissues [35]. Indeed, we could demonstrate a significant higher inhibitory effect of Ritux Fab -Lipoplexes than not functionalized ones on total B lymphocytes proliferation and IgM+ plasma cell differentiation.

The results of this investigation open future pathways to improving the specific delivery and effect of lipoplexes on immunocytes that play a pathogenetic role in different autoimmune conditions. From this initial evidence, certainly more advanced procedures could be exploited in the future to foster functionalization of lipoplexes by exposing Fab of Rituximab to increase B lymphocytes binding and consequently increase functional effect. This investigation also opens the pathway to functionalized lipoplexes with other FDA approved MoAb including anti-CD3 Teplixumab or Otelixizumab [28,29] for specific targeting of T lymphocytes in T cell-mediated diseases such as T1D.

Additional FDA-approved MoAb could be theoretically used for lipoplexes functionalization for their specific targeting delivery. As regards the integrin heterodimer leukocyte function, associated antigen-1 (LFA-1, CD11a) is a classic adhesion molecule that facilitates $\mathrm{T}$ and antigen-presenting cells interaction as well as functioning in activation and trafficking of leukocytes [36]. Antagonism of LFA-1 with MoAb, either alone or in combination with other agents, can induce regulatory tolerance in vivo. Efalizumab, a new generation humanized anti-LFA-1 MoAb, offers at present some promises for clinical application in immunotherapy [37]. LFA-3 (CD58) is a receptor found on the membrane of nearly all human cells. Its interaction with the counter-receptor CD2 generates effective cell-cell adhesion and it is responsible for a costimulatory signal to enhance T lymphocytes responses or modulate anergy / apoptosis. This evidence suggests that it may have therapeutic applications [38]. Alefacept is a chimeric fusion protein composed of CD2-binding portion of LFA3 linked to the Fc region of human IgG1 (LFA3-Fc). Alefacept MoAb was designed to inhibit the activation of memory $\mathrm{T}$ lymphocytes that contribute to chronic inflammation in psoriasis [39].

In conclusion, the present findings indicate the efficiency of functionalized lipoplexes with Fab anti-CD20 (Rituximab) to specifically target B lymphocytes in autoimmune conditions, such as T1D. These results propel future investigations of the applicability of Ritux $x_{F a b}$ functionalized lipoplexes, such as personalized immunotherapy, to other autoimmune disorders, where B lymphocytes are the prevalent pathogenic immunocytes such as SLE.

\section{Materials and Methods}

\subsection{Preparation of Rituximab F(ab')2 and Fab'}

Ritux $_{\mathrm{Fab2}}(\mathrm{CD} 20, \sim 100 \mathrm{kDa})$ was prepared by treatment with pepsin (porcine gastric mucosa pepsin, Sigma-Aldrich, Milan, Italy) using a 20/1 antibody/pepsin ratio (w/w). The reaction was performed in $100 \mathrm{mM}$ acetate buffer $\mathrm{pH}$ 4.0, containing $10 \mathrm{mM}$ ethylenedi- 
aminetetraacetic acid (EDTA). After incubation for $16 \mathrm{~h}$ at $37^{\circ} \mathrm{C}$, the mixture was purified by SEC on a Superdex S200 column using PBS solution (Sigma-Aldrich) as running buffer [40]. Ritux $_{\mathrm{Fab} 2}$ was efficiently reduced to Fab' (Ritux $\mathrm{Fab}, \sim 50 \mathrm{kDa}$ ) by treatment for $2 \mathrm{~h}$ at $37^{\circ} \mathrm{C}$ with $10 \mathrm{mM} \beta$-mercaptoethylamine (MEA) in presence of $2 \mathrm{mM}$ EDTA. After reduction, Ritux $_{\text {Fab }}$ was again purified by SEC on a Superdex S200 gel filtration column in PBS buffer. Fractions containing Ritux Fab2 and Ritux $x_{F a b}$ were analyzed by 12\% SDS-PAGE under native and reducing conditions. The concentrations were determined spectrophotometrically on a Nanodrop 2000C instrument (ThermoFisher instruments, Milan, Italy) using a $\varepsilon_{280 \mathrm{~nm}}=166,060 \mathrm{M}^{-1} \mathrm{~cm}^{-1}$ for Ritux $\mathrm{Fab} 2_{2}$ and a $\varepsilon_{280 \mathrm{~nm}}=83,030 \mathrm{M}^{-1} \mathrm{~cm}^{-1}$ for Ritux $\mathrm{Fab}$.

\subsection{Antibody Fragments Labelling with FITC}

Ritux $_{\text {Fab2 }}$ was randomly labeled with FITC (Sigma Aldrich) by reacting the protein with 10-fold excess FITC in $50 \mathrm{mM} \mathrm{NaHCO}_{3} \mathrm{pH} 8.0$ for $1 \mathrm{~h}$ at RT. The product, named FITC-Ritux $\mathrm{Fab}_{\mathrm{F} 2}$, was extensively dialyzed against PBS buffer at $4{ }^{\circ} \mathrm{C}$, reduced with MEA to obtain FITC-Ritux ${ }_{\mathrm{Fab}}$ and then purified by SEC on a Superdex S200 gel filtration column. The concentration of FITC-Ritux $x_{F a b}$ was determined spectrophotometrically on a Nanodrop 2000C instrument using a $\varepsilon_{495 \mathrm{~nm}}=70,000 \mathrm{M}^{-1} \mathrm{~cm}^{-1}$. The presence of FITC was also evaluated by LC-ESI-TOF-MS analyses.

\subsection{Analytical Characterization of Ritux $x_{F a b 2}$ and Ritux $x_{F a b}$}

Analytical SEC analyses were performed using a Biosep-SEC 2000 column (300 $\mathrm{mm} \times 7.80 \mathrm{~mm}$ Phenomenex) in $50 \mathrm{mM}$ phosphate $100 \mathrm{mM} \mathrm{NaCl} \mathrm{pH} 7.5$ applying a flow rate of $0.6 \mathrm{~mL} / \mathrm{min}$. UV detection was performed at $215 \mathrm{~nm}$. After reduction and alkylation, the products were identified by LC-ESI-TOF analyses using a C4 BioBasic column (50 mm $\times 2.1 \mathrm{~mm}$, ThermoFisher Scientific, Monza, Italy) connected to a LC-ESI-TOF MS system from Agilent (Cernusco sul Naviglio, Italy). Separations were obtained at $0.2 \mathrm{~mL} / \mathrm{min}$ using as solvent A $0.05 \% \mathrm{v} / \mathrm{v}$ trifluoroacetic acid (TFA) in water and as solvent B $0.05 \% v / v$ TFA in acetonitrile applying a linear gradient from $25 \%$ to $65 \%$ solvent B in $20 \mathrm{~min}$. The mass analyzer was set to operate in positive ion scan mode with mass scanning from 100 to $3200 \mathrm{~m} / \mathrm{z}$. The ion source was upgraded from the original Agilent Jet Stream (AJS) source to the dual-sprayer version for improved reference mass delivery. Nitrogen was used as drying and nebulizer gas. The instrument acquired data using the following parameters: drying gas temperature, $325^{\circ} \mathrm{C}$; drying gas flow, $10 \mathrm{~L} / \mathrm{min}$; nebulizer, 20 psi (pound per square inch) sheath gas temperature, $400{ }^{\circ} \mathrm{C}$; sheath gas flow, $11 \mathrm{~L} / \mathrm{min}$; VCap. $3500 \mathrm{~V}$; nozzle, $0 \mathrm{~V}$; fragmentor, $200 \mathrm{~V}$, skimmer, $65 \mathrm{~V}$ and octapole RF Vpp was 750. The instrument was set to extended dynamic range mode $(2 \mathrm{GHz})$. Tuning and calibration were performed before sample running. Data collection and integration were performed using MassHunter workstation software (version B.05.00, Agilent Technologies, Santa Clara, CA, USA). Data were stored in both centroid and profile formats during acquisition. A constant flow of Agilent TOF reference solution through the reference nebulizer allowed the system to continuously correct for mass drift by using two independent reference lock-mass ions, purine $(m / z 119.03632)$ and HP-922 ( $m / z$ 922.000725), to ensure mass accuracy and reproducibility. Target compounds were detected, and the data analyzed and reported using the Agilent MassHunter Qualitative software (Agilent Technologies, Santa Clara, CA, USA).

\subsection{Structural Characterization of Ritux $\mathrm{Fab2}_{2}$ and Ritux $\mathrm{Fab}_{\text {by }}$ CD}

CD spectra were recorded on Ritux $\mathrm{Fab2}_{2}$ and Ritux $\mathrm{Fab}_{\mathrm{b}}$ using a JASCO J-810 spectropolarimeter (Jasco, Cremella, Italy), equipped with a thermostated cell holder (Peltier system) to change the temperature in a controlled way and interfaced with a Neslab RTE-110 water bath. Far-UV CD spectra were recorded in quartz cuvettes 110-QS with $1.0 \mathrm{~mm}$ optical path length (Hellma; Mullheim, Baden, Germany) at a concentration of about $4 \mu \mathrm{M}$ in $20 \mathrm{mM}$ PBS, pH 7.5, at $20^{\circ} \mathrm{C}$. Spectra were collected in the wavelength range between 198 and $280 \mathrm{~nm}$ at a scanning speed of $50 \mathrm{~nm} / \mathrm{min}$, with a data pitch of $0.2 \mathrm{~nm}$, a band width of $1 \mathrm{~nm}$, a response of $4 \mathrm{~s}(\mathrm{sec})$ and a standard sensitivity. Thermal denaturation 
experiments were performed by monitoring changes in ellipticity at $218 \mathrm{~nm}$ by exposure to increasing temperatures between $20^{\circ} \mathrm{C}$ and $95^{\circ} \mathrm{C}$, while heating at $60^{\circ} \mathrm{C} / \mathrm{h}\left(1^{\circ} \mathrm{C} / \mathrm{min}\right)$. Melting points were determined by the method of the first derivative. Four independent spectra for each sample were recorded, averaged and smoothed using the Spectra Manager software, version 1.53. Final spectra were corrected by subtracting the corresponding baseline spectrum obtained under identical conditions.

\subsection{Liposome Formulation}

DOPE, DOTAP, DSPE-PEG2000-Maleimide and NBD-PE were purchased from Avanti Polar Lipids (Alabaster, AL, USA).

All solutions were prepared by weight and buffered at pH 7.4 using $100 \mathrm{mM}$ PBS and the $\mathrm{pH}$ was controlled using $\mathrm{pH}$ meter MeterLab PHM220. Mixed liposomes DOTAP/DOPE/ DSPEPEG2000-Maleimeide (47.5/47.5/5 molar ratio) were prepared by dissolving the required amounts of phospholipids in $1 \mathrm{~mL}$ of chloroform. Subsequently, the organic solvent was removed under a stream of nitrogen gas to obtain a homogeneous film on the wall of the vial. Any trace of the solvent was then removed, keeping the vial under vacuum for $15 \mathrm{~min}$. Then, the dry lipid film was hydrated with $1.0 \mathrm{~mL}$ of $100 \mathrm{mM}$ PBS and sonicated in an ultrasound bath for $30 \mathrm{~min}$. The liposomal suspension (at a concentration of $800 \mu \mathrm{M}$ ) was extruded 10 times at RT, using a thermobarrel extruder system (Northern Lipids Inc., Vancouver, BC, Canada) under nitrogen through a polycarbonate membrane (Nucleopore Track Membrane $25 \mathrm{~mm}$, Whatman, Brentford, UK) having $0.1 \mu \mathrm{m}$ pore size. Lipoplex was prepared by adding $500 \mu \mathrm{L}$ of a siRNA solution $(5.2 \mu \mathrm{M}$ in $0.1 \mathrm{mM}$ buffer $)$ to $500 \mu \mathrm{L}$ of the liposome suspension. The resulting mixture was stirred at RT for $3 \mathrm{~h}$. Successively, lipoplex suspension was shared in two vials: the first aliquot was diluted with an equal amount of buffer in order to obtain a final siRNA concentration of $1.3 \mu \mathrm{M}$ (untargeted lipoplex); the second aliquot was functionalized with Ritux $_{\mathrm{Fab}}$ or Ritux $\mathrm{Fab}_{\mathrm{F}} /$ FITC-Ritux $\mathrm{Fab}$ (90/10, mol/mol) mixture (targeted lipoplex). 0.1 equivalents of $\operatorname{Ritux}_{\mathrm{Fab}}(\sim 0.5 \mathrm{mg} / \mathrm{mL})$ with respect to the maleimide function were added to the liposomal suspension and the reaction was left ON. The unreacted Ritux $x_{\text {Fab }}$ was removed from the lipoplex by using Sepharose CL-4B column, pre-equilibrated with $0.1 \mathrm{M}$

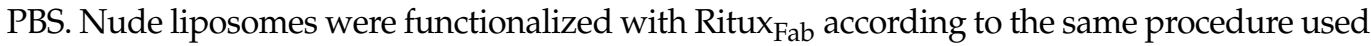
for lipoplex. Liposome formulations for cytofluorimetric analysis were prepared following the same procedure described above, adding the fluorescent phospholipid NBD-PE dye to the lipid solution, during the preparation of the lipid film.

\subsection{DLS Measurements}

Mean diameter of liposomes and lipoplexes before and after functionalization with Ritux $_{\text {Fab }}$ was measured by DLS using a Zetasizer Nano ZS 326 (Malvern Instruments, Westborough, MA, USA). Instrumental settings for the measurements are a backscatter detector at $173^{\circ}$ in automatic modality, temperature of $25^{\circ} \mathrm{C}$ and disposable sizing cuvette as cell. DLS measurements in triplicate were carried out on aqueous samples after centrifugation at RT at 13,000 rpm for $5 \mathrm{~min}$.

\section{7. siRNA Design}

Authentic siRNA sequences were designed to specifically target C1858T PTPN22 gene variant (Rosetta Inpharmatics, Sigma-Aldrich, Saint Louis, MO, USA). The siRNA sequences, sense/antisense (s/a) duplexes were different for mRNA target affinity and did not comprise backbone modifications as previously reported (Italian Patent 102018000005182 released on 26 June 2020. PCT/IT2019/050095 filed on 8 May 2019) [6].

\subsection{Cell Culture}

PBMC were separated by Ficoll-Hypaque (Histopaque, Sigma-Aldrich, Milan, Italy) from sodium heparinized venous blood samples $(5-10 \mathrm{~mL})$ belonging to recruited T1D patients and HD. Subsequently, PBMC were frozen in liquid nitrogen according to standard protocols [31]. The Raji human B lymphocyte cell line (Burkitt's lymphoma) was 
obtained from American Type Culture Collection (ATCC CCL-86). Liquid nitrogen frozen cells were thawed and grown in RPMI-1640 Medium (Gibco ${ }^{\mathrm{TM}}$, ThermoFisher Scientific, Waltham, MA, USA) supplemented with 10\% fetal bovine serum (FBS, GE Healthcare Life Sciences, Logan, UT, USA), 2 mM L-glutamine (EuroClone S.p.A., Milan, Italy) and 1\% penicillin/streptomycin (pen/strep) (EuroClone) according to established protocols [41]. Cells were incubated at $37{ }^{\circ} \mathrm{C}$ and in $5 \% \mathrm{CO}_{2}$ at a density of between 0.1 and $1 \times 10^{6} / \mathrm{mL}$. Cells viability was determined by trypan blue dye staining. Cultures with more than $90 \%$ cell viability were used for the experiments.

\subsection{FACS Analysis}

\subsubsection{Cytofluorimetric Analysis of Raji Cell Line and Human PBMC}

Cryopreserved PBMC were quickly thawed in pre-warmed RPMI-1640 Medium $\left(\right.$ Gibco $^{\mathrm{TM}}$ ) supplemented with 10\% FBS (GE Healthcare Life Sciences), 2 mM L-glutamine (EuroClone) and 1\% pen/strep (EuroClone) and centrifuged at $1200 \mathrm{rpm}$ for $5 \mathrm{~min}$ at RT according to established protocols [31]. Cell pellets of T1D patients, HD and Raji cell line of approximately $5 \times 10^{5}$ cells were allocated for each staining condition.

In two different subsequent experiments (vide infra) of binding analysis, cells were stained with FITC-Ritux ${ }_{\mathrm{Fab}}$ and liposomal suspensions composed of Ritux $\mathrm{Fab}_{\mathrm{Fa}} /$ FITC-Ritux $\mathrm{Fab}_{\mathrm{Fab}}$ $(90 / 10 \mathrm{~mol} / \mathrm{mol})$. Then, the binding of FITC labelled lipoplexes functionalized with Ritux $_{\mathrm{Fab}}$ was verified.

4.9.2. Binding of Ritux $\mathrm{Fab}_{\mathrm{F}}$ and the Liposomal Suspensions Derivatized with Ritux $_{\mathrm{Fab}} /$ FITC-RituxF $\mathrm{ab}(90 / 10 \mathrm{~mol} / \mathrm{mol})$

Cell pellets of Raji cells and human PBMC were incubated with a directly conjugated mouse anti-human MoAb CD19- Brilliant Ultraviolet 737 (BUV737, Clone SJ25C1; BD Biosciences, San Jose, CA, USA) at 1:20 dilution for $20 \mathrm{~min}$ at $4{ }^{\circ} \mathrm{C}$ in the dark. Cells were then washed in $500 \mu \mathrm{L}$ of PBS containing $2 \%$ FBS (FACS medium, EuroClone) by centrifugation at $1200 \mathrm{rpm}$ for $5 \mathrm{~min}$, then incubated with $20 \mu \mathrm{L}$ of $\mathrm{Fab}(\mathrm{CD} 20)$-FITC or the mixture of liposomes decorated with Ritux $\mathrm{Fab}_{\mathrm{F}} /$ FITC-Ritux $\mathrm{Fab}$ (90/10) for $20 \mathrm{~min}$ at $4{ }^{\circ} \mathrm{C}$ in the dark. After incubation, the non-binding lipoplexes were aspirated carefully by fine needle, then cells were washed in $500 \mu \mathrm{L}$ of FACS medium by centrifugation at $1200 \mathrm{rpm}$ for $5 \mathrm{~min}$. Data were acquired using the BD LSR Fortessa X-20 flow-cytometer (Becton and Dickinson (BD Biosciences) and analyzed by using FACSDiva software (BD Biosciences). Dead cells were excluded from analysis by side/forward scatter (SSC/FSC) gating. A minimum of fifty thousand gated events on living cells were collected per dataset.

\subsubsection{Binding Assays of Ritux $\mathrm{Fab}$-Lipoplexes}

Cell pellets of Raji cells and human PBMC were incubated with $50 \mu \mathrm{L}$ of either

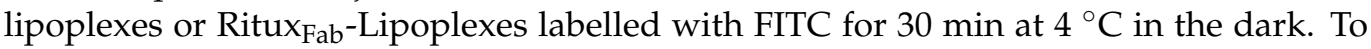
further unravel that the functionalization enriches the binding of lipoplexes to B lymphocytes, the same pellets were also incubated with lipoplexes labelled with the lipophilic fluorophore NBD-PE located in the inner lipid bilayer. In detail, $50 \mu \mathrm{L}$ of NBD-PE labelled lipoplexes were incubated for 30 and $60 \mathrm{~min}$ at $4{ }^{\circ} \mathrm{C}$ in the dark. In both procedures after incubation, the non-binding lipoplexes were aspirated carefully by fine needle and then the cells were washed in $500 \mu \mathrm{L}$ of FACS medium by centrifugation at $1200 \mathrm{rpm}$ for $5 \mathrm{~min}$.

\subsection{Confocal Microscopy Analysis of Ritux $F a b$ Binding to Human B Lymphocytes within PBMC}

Cell pellets of PBMC from one healthy donor were incubated with $20 \mu \mathrm{L}$ of FITC$\operatorname{Ritux}_{\mathrm{Fab}}(2 \mathrm{mg} / \mathrm{mL})$ for $30 \mathrm{~min}$ at $4{ }^{\circ} \mathrm{C}$ in the dark. After the incubation, the non-binding lipoplexes were aspirated by fine needle and then the cells were washed in $1 \mathrm{~mL}$ of PBS buffer for two times by centrifugation at $700 \mathrm{rpm}$ for $5 \mathrm{~min}$ and fixed with paraformaldehyde 4\% $(w / v)$ (Sigma-Aldrich) for $10 \mathrm{~min}$. Fixed cell suspensions were distributed drop wise onto positive charged microscope slides (Super Frost plus, Menzel-Glaser, Germany) 
and dried at $37^{\circ} \mathrm{C}$. After rehydration in PBS, cells were incubated with blocking solution PBS supplemented with bovine serum albumin (Sigma-Aldrich) 5\% (w/v) for 30 min at RT.

Cells were subsequently incubated with primary mouse anti-human MoAb CD3 BV510 (Clone UCHT1, 1:30 dilution, BD Biosciences) for $60 \mathrm{~min}$ at RT or with primary mouse anti-human MoAb CD19 (Clone HIB19, 1:10 dilution, BD Biosciences) ON at $4{ }^{\circ} \mathrm{C}$ followed, after washing, by goat anti-mouse AlexaFluor 647 secondary antibody (1:400 dilution, ThermoFisher Scientific) for $1 \mathrm{~h}$ at RT. Another set of cells was double stained by combining the same antibodies. After washing with PBS, cells were incubated with SYTO ${ }^{\text {TM}} 82$ Orange Fluorescent dye (1:1000 dilution, ThermoFisher Scientific) for $10 \mathrm{~min}$ at RT to counterstain nuclei. Thereafter, cells were washed with PBS and mounted in PBS 40\%/glycerol 60\% solution and cover-slipped before being evaluated by Leica TCS AOBS-SP8X laser-scanning confocal microscope (Leica Microsystems, Mannheim, Germany) equipped with tunable white light laser (WLL, 470-670 nm of wavelength) source, $405 \mathrm{~nm}$ diode laser, 3 PMT, 2 HyD detectors and an acousto-optical beam splitter (AOBS) that allowed the separation of multiple fluorescences, using a $63 \times(1.42$ NA oil) objective. Optical single sections were acquired with a scanning mode format of $512 \times 512$ pixels, sampling speed of $400 \mathrm{~Hz}$ (pixel size of $0.103 \mu \mathrm{m}$ ), and Z-reconstructions of serial single optical sections were carried out with an electronic zoom at 3.5. Fluorochromes unmixing was performed by acquisition of automated-sequential collection of multi-channel images, in order to reduce spectral crosstalk between channels.

\subsection{Functional Assay on CpG-Stimulated B Lymphocytes}

In order to verify the functional effect of Fab functionalized lipoplexes, we tested them on a functional assay in which PBMC of an autoimmune condition, that is, T1D were challenged with CpG oligodeoxynucleotides (Hycult Biotechnology, Uden, The Netherlands).

\subsubsection{Human Patients PBMC}

PBMC of eight T1D patients heterozygous carriers of the C1858T PTPN22 variant were recruited from the Endocrinology Division at Bambino Gesù Children's Hospital. All patients were recruited during long-term disease. The mean age at onset of disease was 8.9 years (age range $2-12.7$ ), and the mean disease duration was 9.8 years (age range 4.4-19.2). The mean age at referral of the patients was 18.7 years (age range 11.6-31.1; two females, six males) (Table 1). Diabetics' demographic and clinical characteristics are shown in Table 1. The patients' sera were assayed for glutamic acid decarboxylase (GADA, isoform 65), protein tyrosine phosphatase insulinoma-associated antigen 2 (IA2) and anti-insulin (IAA) antibodies (Abs) by radioimmunoassay, for Abs to thyroglobulin (Tg), thyroperoxidase (TPO) and transglutaminase (tTGA) by chemiluminescence (ADVIA Centaur analyzer, Siemens Healthcare, Germany) and to parietal cells (PCA) and adrenal cortex by indirect immunofluorescence (IFL). The T1D patients presented associated autoimmune disorders, that is, autoimmune thyroid disease (Graves' disease) (patient number $\left(\mathrm{N}^{\circ}\right)$ 4) and vitiligo (patient $\mathrm{N}^{\circ}$ 8) (Table 1).

All recruited patients were unrelated. All subjects entered the study after written informed consent was obtained. The investigation was approved by the local Institutional Review Board (IRB) of Bambino Gesù Children's Hospital, which regulates human samples usage for experimental studies (Study protocol no. RF-2019-12369889); all procedures followed were in accordance with institutional guidelines. The informed consent was obtained from the next of kin in case of children. Consent on behalf of children was written. Participant consent was recorded using a paper-based inventory system. The IRB approved the consent procedure. 
Table 1. Demographic, genetic and clinical characteristics of patients of the present study.

\begin{tabular}{|c|c|c|c|c|c|c|c|c|}
\hline Patient & Gender & $\begin{array}{c}\text { Age of } \\
\text { Disease Onset } \\
\text { (Years) }\end{array}$ & $\begin{array}{c}\text { Age at } \\
\text { Referral } \\
\text { (Years) }\end{array}$ & $\begin{array}{c}\text { Duration of } \\
\text { Disease } \\
\text { (Years) }\end{array}$ & $\begin{array}{l}\text { Autoimm-ne } \\
\text { Disorders }\end{array}$ & $\begin{array}{l}\text { PTPN22 } \\
\text { Genotype }\end{array}$ & Islet Related AABs & Other AABs \\
\hline 1 & M & 11.1 & 19.4 & 8.3 & T1D & $1858 \mathrm{C} / 1858 \mathrm{~T}$ & $\begin{array}{c}\text { GADA } 5.3 \mathrm{U} / \mathrm{mL} \text {; } \\
\text { IAA } 11 \% \\
\text { IA2 } 29 \mathrm{U} / \mathrm{mL}\end{array}$ & $\begin{array}{l}\text { tTGA } 0.2 \mathrm{U} / \mathrm{mL} \text {; } \\
\text { TPO } 40.5 \mathrm{U} / \mathrm{mL} ; \\
\text { Tg < } 20.0 \mathrm{UI} / \mathrm{mL}\end{array}$ \\
\hline 2 & M & 8.6 & 18.1 & 9.5 & T1D & $1858 \mathrm{C} / 1858 \mathrm{~T}$ & $\begin{array}{c}\text { GADA } 0.3 \mathrm{U} / \mathrm{mL} ; \\
\text { IAA } 8 \% \\
\text { IA2 } 2.0 \mathrm{U} / \mathrm{mL}\end{array}$ & $\begin{array}{c}\text { tTGA } 0.2 \mathrm{U} / \mathrm{mL} \\
\text { TPO } 40.3 \mathrm{U} / \mathrm{mL} \\
\text { Tg } 17.3 \mathrm{U} / \mathrm{mL}\end{array}$ \\
\hline 3 & M & 10.5 & 18 & 7.5 & T1D & $1858 \mathrm{C} / 1858 \mathrm{~T}$ & $\begin{array}{c}\text { GADA } 16 \mathrm{U} / \mathrm{mL} ; \\
\text { IAA } 4.1 \% \\
\text { IA2 } 2.0 \mathrm{U} / \mathrm{mL}\end{array}$ & $\begin{array}{c}\text { tTGA } 0.2 \mathrm{U} / \mathrm{mL} ; \\
\mathrm{TPO}<28.0 \mathrm{U} / \mathrm{mL} ; \\
\mathrm{Tg}<20.0 \mathrm{UI} / \mathrm{mL}\end{array}$ \\
\hline 4 & M & 11.9 & 31.1 & 19.2 & $\begin{array}{l}\text { Graves' } \\
\text { disease } \\
\text { T1D }\end{array}$ & $1858 \mathrm{C} / 1858 \mathrm{~T}$ & & $\begin{array}{l}\text { tTGA } 0.4 \mathrm{U} / \mathrm{mL} \\
\text { TPO > } 1300 \mathrm{U} / \mathrm{mL} ; \\
\mathrm{Tg}>\mathbf{2 5 0 0} \mathrm{U} / \mathrm{mL}\end{array}$ \\
\hline 5 & M & 12.7 & 18.9 & 6.3 & T1D & $1858 \mathrm{C} / 1858 \mathrm{~T}$ & $\begin{array}{c}\text { GADA } 5.3 \mathrm{U} / \mathrm{mL} ; \\
\text { IAA } 22 \% \\
\text { IA2 } 2.3 \mathrm{U} / \mathrm{mL}\end{array}$ & $\begin{array}{c}\text { tTGA < } 1.9 \mathrm{CU} ; \\
\mathrm{TPO}<28.0 \mathrm{U} / \mathrm{mL} ; \\
\mathrm{Tg}<20.0 \mathrm{UI} / \mathrm{mL}\end{array}$ \\
\hline 6 & $\mathrm{~F}$ & 2 & 15.8 & 13.7 & T1D & $1858 \mathrm{C} / 1858 \mathrm{~T}$ & $\begin{array}{c}\text { GADA } 18.6 \mathrm{U} / \mathrm{mL} ; \\
\text { IAA } \mathbf{6 7 . 0 \%} \\
\text { IA2 } 0.1 \mathrm{U} / \mathrm{mL}\end{array}$ & $\begin{array}{c}\text { tTGA } 0.20 \mathrm{U} / \mathrm{mL} ; \\
\text { TPO } 19.9 \mathrm{U} / \mathrm{mL} ; \\
\text { Tg } 15.2 \mathrm{U} / \mathrm{mL}\end{array}$ \\
\hline 7 & M & 7.1 & 11.6 & 4.4 & T1D & $1858 \mathrm{C} / 1858 \mathrm{~T}$ & $\begin{array}{c}\text { GADA12.2 U/mL; } \\
\text { IAA } 7.4 \% \\
\text { IA2 } 2.7 \mathrm{U} / \mathrm{mL}\end{array}$ & $\begin{array}{l}\text { tTGA 1.9 CU; } \\
\text { TPO } 30.11 \mathrm{U} / \mathrm{mL} ; \\
\mathrm{Tg}<20.0 \mathrm{UI} / \mathrm{mL}\end{array}$ \\
\hline 8 & $\mathrm{~F}$ & 7.2 & 16.7 & 9.5 & $\begin{array}{c}\text { T1D } \\
\text { Vitiligo }\end{array}$ & $1858 \mathrm{C} / 1858 \mathrm{~T}$ & $\begin{array}{l}\text { GADA } 1.8 \mathrm{U} / \mathrm{mL} ; \\
\text { IAA } 2.4 \% \\
\text { IA2 } 15 \mathrm{U} / \mathrm{mL}\end{array}$ & $\begin{array}{l}\text { tTGA } 0.2 \mathrm{U} / \mathrm{mL} \text {; } \\
\text { TPO } 35.9 \mathrm{U} / \mathrm{mL} ; \\
\mathrm{Tg}<20.0 \mathrm{UI} / \mathrm{mL}\end{array}$ \\
\hline
\end{tabular}

\subsubsection{Stimulation of PBMC with CpG and Proliferation Assay}

Liquid-nitrogen frozen PBMC from T1D patients were quickly thawed as previously described [31]. Cells were centrifuged at $1200 \mathrm{rpm}$ for $5 \mathrm{~min}$ at RT and seeded in 48-well plates (flat bottom, Falcon, Corning, NY, USA) at a density of $1.5 \times 10^{6}$ per well in a final volume of $250 \mu \mathrm{L}$ of FBS-free RPMI 1640 medium containing L-glutamine $(2 \mathrm{mM})$ and treated with different doses of lipoplex and Ritux $\mathrm{Fab}$-Lipoplex (80 and 100 pmols of siRNA). After approximately $16 \mathrm{~h}(\mathrm{ON})$ of transfection, cells were washed in complete RPMI by $1200 \mathrm{rpm}$ centrifugation for $5 \mathrm{~min}$ at RT.

Before stimulation, PBMC were labeled with 5-chloromethylfluorescein diacetate (CMFDA) (CellTracker, Invitrogen, Molecular Probes, Eugene, OR, USA) at a final concentration of $0.1 \mathrm{mg} / \mathrm{mL}$ and cultured at $7.5 \times 10^{5}$ cells per well in 96-well plates (Falcon, Labware BD Biosciences, Oxnard, CA, USA) in complete RPMI 1640 medium supplemented with $10 \%$ FBS (Hyclone, South Logan, UT, USA), L-glutamine $(2 \mathrm{mM})$ and $1 \%$ pen/strep. The cells were stimulated with human $\mathrm{CpG}$ at a concentration of $5 \mathrm{mg} / \mathrm{mL}$ and supplemented with IL-2 (25 IU/mL, Sigma Aldrich) according to established protocol [31]. IL-2 was added to the cultures because we found that it improved cell survival in cryopreserved pathological samples without altering cell function. The cells were incubated for 4 days at $37^{\circ} \mathrm{C}$ in a humidified atmosphere containing $5 \% \mathrm{CO}_{2}$. In parallel, basal PBMC cultures were set up by incubating PBMC from the same individual with complete medium plus IL-2 as a control. After 4 days of $\mathrm{CpG}$ stimulation, $\mathrm{PBMC}$ were harvested from the culture plates and washed by centrifugation at $1200 \mathrm{rpm}$ for $5 \mathrm{~min}$ at RT in FACS medium. To identify $B$ cell subsets, single-cell suspensions were stained with the appropriate combination of the following directly conjugated MoAbs: CD19-BUV 737 (1:20 dilution; BD Biosciences), CD38-PECy7 (1:90 dilution; BD Biosciences), CD27-PE (1:20 dilution; BD Biosciences) and IgM-Alexa Fluor 647 (1:400 dilution; Jackson ImmunoResearch, West Baltimore Pike, PA, USA). Cells were incubated for $20 \mathrm{~min}$ in the dark at $4{ }^{\circ} \mathrm{C}$. After labelling, cells were washed by centrifugation at $1200 \mathrm{rpm}$ for $5 \mathrm{~min}$ at $4{ }^{\circ} \mathrm{C}$ in FACS medium. Data were acquired using BD LSR Fortessa X-20 flow-cytometer (BD Biosciences) and analyzed by using FACSDiva software (BD Biosciences). Dead cells were excluded from the analysis by side/forward scatter gating. A minimum of fifty thousand gated events on living cells were collected per dataset. 


\subsection{Statistical Analysis}

Values are expressed as means \pm SEM. Differences between each test condition were assessed by one-way ANOVA followed by Bonferroni and Dunnett's multiple comparison tests, for the functional assay on T1D PBMC. Differences between CD19+/Ritux $\mathrm{Fab}_{\text {ab }}$ and CD19+/FITC-Ritux ${ }_{\mathrm{Fab}}$ cells were assessed by the unpaired Mann-Whitney $t$-test, for the binding of FITC-Ritux $\mathrm{Fab}_{\mathrm{b}}$ functionalized liposome to Raji cells and lipoplexes functionalized with $\operatorname{Ritux}_{\mathrm{Fab}} /$ FITC-Ritux $\mathrm{Fab}(90 / 10 \mathrm{~mol} / \mathrm{mol})$ to HD PBMC experiments. Differences

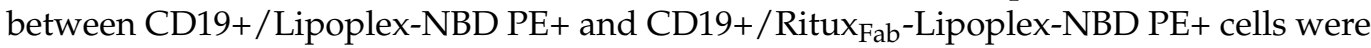
determined by the unpaired Mann-Whitney $t$-test, for the binding of functionalized NBD PE-lipoplexes to Raji cells and human B lymphocytes within the PBMC pool. The statistical study was performed with GraphPad Prism (version 7, San Diego, CA, USA). The difference was considered statistically significant at $p<0.05$.

\section{Patents}

Italian Patent 102018000005182 released on 26 June 2020. PCT/IT2019/050095 filed on 8 May 2019. Inventor: Dr. Alessandra Fierabracci. Property: Bambino Gesù Children's Hospital, IRCCS, Rome, Italy.

Supplementary Materials: The following supporting information can be downloaded at: https: //www.mdpi.com/article/10.3390/ijms23010408/s1.

Author Contributions: A.F., G.M. Conceptualization; A.A. (Andrea Arena), E.B. Data curation; E.B., A.A. (Andrea Arena), S.P., L.A.C., E.G. Formal analysis; A.F. Funding acquisition; A.F., E.B., A.A. (Andrea Arena), O.P., A.A. (Antonella Accardo), A.S. Investigation; A.F., E.B., A.A. (Andrea Arena), A.A. (Antonella Accardo), A.S., E.R. Methodology; A.F. Project administration; A.F., R.S., G.M., E.G., S.P., A.A. (Antonella Accardo), T.C. Resources; E.B., A.A. (Andrea Arena), S.P., L.A.C., E.G. Software; A.F., G.M. Supervision; A.F., G.M. Validation; E.B., A.A. (Andrea Arena), A.F., G.M, A.A. (Antonella Accardo), A.S., E.G. Visualization; A.F., A.A. (Andrea Arena), G.M, A.A. (Antonella Accardo), A.S. Writing—original draft; A.F., E.B., G.M., A.A. (Antonella Accardo), A.S. Writing—review \& editing. A.A. (Andrea Arena), E.B. contributed equally to this work. All authors have read and agreed to the published version of the manuscript.

Funding: This work was supported by the Italian Ministry of Health Ricerca Finalizzata RF-201912369889 to A.F.

Institutional Review Board Statement: The study was conducted according to the guidelines of the Declaration of Helsinki, and approved by the Institutional Review Board of Bambino Gesù Children's Hospital, which regulates human samples usage for experimental studies (Study protocol $\mathrm{n}^{\circ}$. RF-2019-12369889).

Informed Consent Statement: The informed consent was obtained from the next of kin in case of children. Consent on behalf of children was written. Participant consent was recorded using a paper-based inventory system. The Institutional Review Board approved the consent procedure.

Data Availability Statement: The original contributions presented in the study are included in the article/Supplementary Materials; further inquiries can be directed to the corresponding author.

Acknowledgments: We thank Giuseppe Bianco (Unit of Hospital Pharmacy, Bambino Gesù Children's Hospital, IRCCS, Rome, Italy) for providing Rituximab.

Conflicts of Interest: The authors declare no conflict of interest.

\section{References}

1. Sanz, I.; Lund, F. Complexity and heterogeneity-the defining features of autoimmune disease. Curr. Opin. Immunol. 2019, 61, iii-vi. [CrossRef] [PubMed]

2. Kahaly, G.J.; Frommer, L. Autoimmune polyglandular diseases. Best Pract. Res. Clin. Endocrinol. Metab. 2019, $33,101344$. [CrossRef]

3. Norris, J.M.; Johnson, R.K.; Stene, L.C. Type 1 diabetes-early life origins and changing epidemiology. Lancet Diabetes Endocrinol. 2020, 8, 226-238. [CrossRef] 
4. Gianchecchi, E.; Fierabracci, A. Recent Advances on Microbiota Involvement in the Pathogenesis of Autoimmunity. Int. J. Mol. Sci. 2019, 20, 283. [CrossRef] [PubMed]

5. Fierabracci, A. Unravelling the role of infectious agents in the pathogenesis of human autoimmunity: The hypothesis of the retroviral involvement revisited. Curr. Mol. Med. 2009, 9, 1024-1033. [CrossRef]

6. Pellegrino, M.; Ceccacci, F.; Petrini, S.; Scipioni, A.; De Santis, S.; Cappa, M.; Mancini, G.; Fierabracci, A. Exploiting novel tailored immunotherapies of type 1 diabetes: Short interfering RNA delivered by cationic liposomes enables efficient down-regulation of variant PTPN22 gene in T lymphocytes. Nanomedicine 2019, 18, 371-379. [CrossRef]

7. Woittiez, N.J.; Roep, B.O. Impact of disease heterogeneity on treatment efficacy of immunotherapy in type 1 diabetes: Different shades of gray. Immunotherapy 2015, 7, 163-174. [CrossRef]

8. Atkinson, M.A.; Ogle, G.D. Improving diabetes care in resource-poor countries: Challenges and opportunities. Lancet Diabetes Endocrinol. 2013, 1, 268-270. [CrossRef]

9. Musette, P.; Bouaziz, J.D.; Musette, P.B. Cell Modulation Strategies in Autoimmune Diseases: New Concepts. Front. Immunol. 2018, 9, 622. [CrossRef]

10. Wortel, C.M.; Heidt, S. Regulatory B cells: Phenotype, function and role in transplantation. Transpl. Immunol. 2017, 41, 1-9. [CrossRef]

11. Berghen, N.; Vulsteke, J.B.; Westhovens, R.; Lenaerts, J.; De Langhe, E. Rituximab in systemic autoimmune rheumatic diseases: Indications and practical use. Acta Clin. Belg. 2019, 74, 272-279. [CrossRef]

12. Van der Kolk, L.E.; Baars, J.W.; Prins, M.H.; van Oers, M.H. Rituximab treatment results in impaired secondary humoral immune responsiveness. Blood 2002, 100, 2257-2259. [CrossRef]

13. Lessard, C.J.; Ice, J.A.; Adrianto, I.; Wiley, G.B.; Kelly, J.A.; Gaffney, P.M.; Montgomery, C.G.; Moser, K.L. The genomics of autoimmune disease in the era of genome-wide association studies and beyond. Autoimmun. Rev. 2012, 11, 267-275.

14. Tobón, G.J.; Pers, J.O.; Cañas, C.A.; Rojas-Villarraga, A.; Youinou, P.; Anaya, J.M. Are autoimmune diseases predictable? Autoimmun. Rev. 2012, 11, 259-266. [CrossRef] [PubMed]

15. Fierabracci, A.; Milillo, A.; Locatelli, F.; Fruci, D. The putative role of endoplasmaticreticulum aminopeptidases in autoimmunity: Insights from genome-wide association studies. Autoimmun. Rev. 2012, 12, 281-288. [CrossRef] [PubMed]

16. Wang, K.; Zhu, Q.; Lu, Y.; Lu, H.; Zhang, F.; Wang, X.; Fan, Y. CTLA-4+49 G/a polymorphism confers autoimmune disease risk: An updated meta-analysis. Genet. Test. Mol. Biomark. 2017, 21, 222-227. [CrossRef] [PubMed]

17. Vang, T.; Congia, M.; Macis, M.D.; Musumeci, L.; Orrú, V.; Zavattari, P.; Nika, K.; Tautz, L.; Taskén, K.; Cucca, F.; et al Autoimmune associated lymphoid tyrosine phosphatase is a gain-of-function variant. Nat. Genet. 2005, 37, 1317-1319. [CrossRef] [PubMed]

18. Gianchecchi, E.; Palombi, M.; Fierabracci, A. The putative role of the C1858T polymorphism of protein tyrosine phosphatase PTPN22 gene in autoimmunity. Autoimmun. Rev. 2013, 12, 717-725. [CrossRef] [PubMed]

19. Bottini, N.; Musumeci, L.; Alonso, A.; Rahmouni, S.; Nika, K.; Rostamkhani, M.; MacMurray, J.; Meloni, G.F.; Lucarelli, P.; Pellecchia, M.; et al. A functional variant of lymphoid tyrosine phosphatase is associated with type I diabetes. Nat. Genet. 2004, 36, 337-338. [CrossRef]

20. Bottini, N.; Vang, T.; Cucca, F.; Mustelin, T. Role of PTPN22 in type 1 diabetes and other autoimmune diseases. Semin. Immunol. 2006, 18, 207-213. [CrossRef]

21. Zheng, W.; She, J.X. Genetic association between a lymphoid tyrosine phosphatase PTPN22) and type 1 diabetes. Diabetes 2005, 54, 906-908. [CrossRef]

22. Velaga, M.R.; Wilson, V.; Jennings, C.E.; Owen, C.J.; Herington, S.; Donaldson, P.T.; Ball, S.G.; James, R.A.; Quinton, R.; Perros, P.; et al. The codon 620 tryptophan allele of the lymphoid tyrosine phosphatase (LYP) gene is a major determinant of Graves' disease. J. Clin. Endocrinol. Metab. 2004, 89, 5862-5865. [CrossRef]

23. Vandiedonck, C.; Capdevielle, C.; Giraud, M.; Krumeich, S.; Jais, J.P.; Eymard, B.; Tranchant, C.; Gajdos, P.; Garchon, H.J. Association of the PTPN22*R620W polymorphism with autoimmune myasthenia gravis. Ann. Neurol. 2006, 59, $404-407$. [CrossRef]

24. Ferreira, R.C.; Castro Dopico, X.; Oliveira, J.J.; Rainbow, D.B.; Yang, J.H.; Trzupek, D.; Todd, S.A.; McNeill, M.; Steri, M.; Orrù, V.; et al. Chronic Immune Activation in Systemic Lupus Erythematosus and the Autoimmune PTPN22 Trp620 Risk Allele Drive the Expansion of FOXP3+ Regulatory T Cells and PD-1 Expression. Front. Immunol. 2019, 10, 2606.

25. Jagiello, P.; Aries, P.; Arning, L.; Wagenleiter, S.E.; Csernok, E.; Hellmich, B.; Gross, W.L.; Epplen, J.T. The PTPN22 620W allele is a risk factor for Wegener's granulomatosis. Arthritis Rheum 2005, 52, 4039-4043. [CrossRef] [PubMed]

26. Begovich, A.B.; Carlton, V.E.H.; Honigberg, L.A.; Schrodi, S.J.; Chokkalingam, A.P.; Alexander, H.C.; Ardlie, K.J.; Huang, Q.; Smith, A.M.; Spoerke, J.M.; et al. A missense single-nucleotide polymorphismin a gene encoding a protein tyrosine phosphatase (PTPN22) is associated with rheumatoid arthritis. Am. J. Hum. Genet. 2004, 75, 330-337. [CrossRef] [PubMed]

27. Perri, V.; Pellegrino, M.; Ceccacci, F.; Scipioni, A.; Petrini, S.; Gianchecchi, E.; Lo Russo, A.; De Santis, S.; Mancini, G.; Fierabracci, A. Use of short interfering RNA delivered by cationic liposomes to enable efficient down-regulation of PTPN22 gene in human T lymphocytes. PLoS ONE 2017, 12, e0175784. [CrossRef] [PubMed]

28. Gaglia, J.; Kissler, S. Anti-CD3 Antibody for the Prevention of Type 1 Diabetes: A Story of Perseverance. Biochemistry 2019, 58, 4107-4111. [CrossRef] [PubMed] 
29. Herold, K.C.; Bundy, B.N.; Long, S.A.; Bluestone, J.A.; DiMeglio, L.A.; Dufort, M.J.; Gitelman, S.E.; Gottlieb, P.A.; Krischer, J.P.; Linsley, P.S.; et al. An Anti-CD3 Antibody, Teplizumab, in Relatives at Risk for Type 1 Diabetes. New Engl. J. Med. 2019, 381, 603-613. [CrossRef]

30. Crickx, E.; Weill, J.C.; Reynaud, C.A.; Mahévas, M. Anti-CD20-mediated B-cell depletion in autoimmune diseases: Successes, failures and future perspectives. Kidney Int. 2020, 97, 885-893. [CrossRef]

31. Gianchecchi, E.; Crinò, A.; Giorda, E.; Luciano, R.; Perri, V.; Lorusso, A.; Cappa, M.; Rosado, M.M.R.; Fierabracci, A. Altered B cell homeostasis and toll-like receptor 9-driven response in type 1 diabetes carriers of the C1858T PTPN22 allelic variant: Implications in the disease pathogenesis. PLOS ONE 2014, 9, 110755. [CrossRef]

32. Rieck, M.; Arechiga, A.; Onengut-Gumuscu, S.; Greenbaum, C.; Concannon, P.; Buckner, J.H. Genetic variation in PTPN22 corresponds to altered function of T and B lymphocytes. J. Immunol. 2007, 179, 4704-4710. [CrossRef]

33. Kennedy, P.J.; Sousa, F.; Ferreira, D.; Pereira, C.; Nestor, M.; Oliveira, C.; Granja, P.L.; Sarmento, B. Fab-conjugated PLGA nanoparticles effectively target cancer cells expressing human CD44v6. Acta Biomater. 2018, 81, 208-218. [CrossRef]

34. Accardo, A.; Tesauro, D.; Morelli, G. Peptide-based targeting strategies for simultaneous imaging and therapy with nanovectors. Polym. J. 2013, 45, 481-493. [CrossRef]

35. Bae, Y.H.; Park, K. Targeted drug delivery to tumors: Myths, reality and possibility. J. Control Release 2011, 153, 198-205. [CrossRef]

36. Nicolls, M.R.; Gill, R.G. LFA-1 (CD11a) as a therapeutic target. Am. J. Transplant. 2006, 6, 27-36. [CrossRef]

37. Talamonti, M.; Spallone, G.; Di Stefani, A.; Costanzo, A.; Chimenti, S. Efalizumab. Expert Opin Drug Saf. 2011, 10, $239-251$. [CrossRef]

38. Brown, M.H.; Cantrell, D.A.; Brattsand, G.; Crumpton, M.J.; Gullberg, M. The CD2 antigen associates with the T-cell antigen receptor CD3 antigen complex on the surface of human T lymphocytes. Nature 1989, 339, 551-553. [CrossRef] [PubMed]

39. Heffernan, M.P.; Leonardi, C.L. Alefacept for psoriasis. Semin. Cutan Med. Surg. 2010, 29, 53-55. [CrossRef] [PubMed]

40. Selis, F.; Focà, G.; Sandomenico, A.; Marra, C.; Di Mauro, C.; Saccani Jotti, G.; Scaramuzza, S.; Politano, A.; Sanna, R.; Ruvo, M.; et al. Pegylated Trastuzumab Fragments Acquire an Increased in Vivo Stability but Show a Largely Reduced Affinity for the Target Antigen. Int. J. Mol. Sci. 2016, 17, 491. [CrossRef] [PubMed]

41. Rich, S.A.; Bose, M.; Tempst, P.; Rudofs, U.H. Purification, Microsequencing, and Immunolocalization of p36, a New Interferon- $\alpha$ induced Protein That Is Associated with Human Lupus Inclusions. J. Biol. Chem. 1996, 271, 1118-1126. [CrossRef] [PubMed] 